\title{
BIOSYNTHESIS, PURIFICATION AND CHARACTERIZATION OF ENDOGLUCANASE FROM A XYLANASE PRODUCING STRAIN ASPERGILLUS NIGER B03
}

\author{
Georgi Todorov Dobrev, Boriana Yordanova Zhekova*
}

Department of Biochemistry and Molecular Biology, University of Food Technologies, 26 Maritza Blvd., 4000 Plovdiv, Bulgaria.

Submitted: January 29, 2010; Returned to authors for corrections: April 15, 2011; Approved: January 16, 2012.

\begin{abstract}
An extracellular endoglucanase was isolated from the culture liquid of xylanase producing strain Aspergillus niger B03. The enzyme was purified to a homogenous form, using consecutive ultrafiltration, anion exchange chromatography, and gel filtration. Endoglucanase was a monomer protein with a molecular weight of 26,900 Da determined by sodium dodecyl sulfate-polyacrylamide gel electrophoresis, and 28,800 Da determined by gel filtration. The optimal $\mathrm{pH}$ and temperature values for the enzyme action were 3.5 and $65{ }^{\circ} \mathrm{C}$ respectively. Endoglucanase was stable at $40{ }^{\circ} \mathrm{C}$, pH 3.0 for $210 \mathrm{~min}$. The substrate specificity of the enzyme was determined with carboxymethyl cellulose, filter paper, and different glycosides. Endoglucanase displayed maximum activity in the case of carboxymethyl cellulose, with a $\mathrm{K}_{\mathrm{m}}$ value of $21.01 \mathrm{mg} / \mathrm{mL}$. The substrate specificity and the pattern of substrate degradation suggested that the enzyme is an endoglucanase. Endoglucanase showed a synergism with endoxylanase in corn cobs hydrolysis.
\end{abstract}

Key words: endoglucanase; purification; characterization; Aspergillus niger; endoxylanase

\section{INTRODUCTION}

The hydrolysis of lignocellulosic biomass to fermenting sugars, which can be used for ethanol biosynthesis, is one of the possibilities for production of alternative energy sources. Annually about 7 million tons of lignocellulosic wastes from the grain-producing industry are deposited from the membercountries of the European Union (3). Lignocellulosic biomass includes various agricultural residues (straws, hulls, stems, and stalks), deciduous and coniferous woods, municipal biodegradable wastes, waste from the pulp and the paper industry and herbaceous energy crops. The composition of lignocellulosic biomass varies significantly. The main polysaccharide components are cellulose, representing 35-50\% of the biomass and xylan, which constitutes about $30 \%$ (3).

The process of ethanol production from lignocellulosic biomass includes delignification of the plant biomass and hydrolysis of cellulose and hemycellulose to monosaccharides (2). The hydrolysis process can be performed by treatment with acids at high temperatures or by enzyme action. The acidic hydrolysis acquires a significant energy consumption and acid resisting equipment, which makes the process more expensive.

*Corresponding Author. Mailing address: Department of Biochemistry and Molecular Biology, University of Food Technologies, 26 Maritza Blvd., 4000 Plovdiv, Bulgaria.; E-mail: zhekova_b@yahoo.com 
The enzymatic hydrolysis does not have these disadvantages. Because of the complex composition of lignocellulosic biomass, the synergistic action of several enzymes (endoglucanases, EC 3.2.1.4; $\beta$-glucosidases, EC 3.2.1.21; xylanases, EC 3.2.1.8 and $\beta$-xylosidases, EC 3.2.1.37) is needed for complete hydrolysis (22).

Lignocellulose degradation enzymes are produced by various groups of microorganisms, including moulds, bacteria, and yeasts. Filamentous fungi have been widely studied for their ability to produce cellulolytic and xylanolytic enzymes (1, 4). A characteristic feature of the mould strains is their ability to produce simultaneously cellulose and xylan degrading enzymes. Cellulases and xylanases produced by a certain strain may act synergistically during the hydrolysis of lignicellulosic biomass $(10,18,19,20)$.

The isolation, purification, and characterization of the separate enzymes, involved in lignocellulosic biomass hydrolysis give possibility for their effective application. The aim of the present research is to describe the biosynthesis, isolation and characterization of an endoglucanase from a xylanase producing strain Aspergillus niger B03.

\section{MATERIALS AND METHODS}

\section{Strain Cultivation}

The research was performed with an industrial xylanase producing strain Aspergillus niger B03 from Biovet JSC. For endoglucanase biosynthesis the strain was cultivated in $15 \mathrm{~L}$ laboratory bioreactor Aplikon as described previously $(6,7)$. The biomass was removed by filtration and the culture filtrate was used for the enzyme isolation.

\section{Endoglucanase Purification}

Endoglucanase purification was performed by ultrafiltration using $10 \mathrm{kDa}$ membrane, anion-exchange chromatography and a subsequent gel filtration on a chromatographic system (Pharmacia biotech). Anion-exchange chromatography was carried out on a DEAE-Sephadex A50 column $(2.6 \times 40 \mathrm{~cm})$ equilibrated with $10 \mathrm{mM}$ sodium acetate buffer with $\mathrm{pH}$ 5.5. A sample, containing $51.25 \mathrm{mg}$ of protein was loaded onto the column and the unbound protein was washed with the buffer solution. Elution was performed with gradient of $\mathrm{NaCl}$ at a flow rate of $9.6 \mathrm{~mL} / \mathrm{h}$. Fractions of $11 \mathrm{~mL}$ were collected, monitored at $280 \mathrm{~nm}$, and assayed for CMCase activity and protein content. CMCase active fractions were subjected to gel filtration on Sephadex G 75 column ( 2.6 x 70.0 $\mathrm{cm})$. Elution was performed with $0.05 \mathrm{M}$ solution of $\mathrm{NaCl}$ at a flow rate of $19.8 \mathrm{~mL} / \mathrm{h}$, fractions of $7.0 \mathrm{~mL}$ were collected, and the standard assays were performed.

\section{Determination of Endoglucanase Molecular Weight}

The molecular weight of endoglucanase was determined by sodium dodecyl sulfate-polyacrylamide gel electrophoresis (SDS-PAGE) and gel filtration. SDS-PAGE was performed by the method of Laemli (11) with $10.0 \%$ polyacrylamide gel at a constant current of $10 \mathrm{~mA}$. The following protein calibration kit (Merck) was used: ovotransferrin (78,000 Da), albumin $(66,250 \mathrm{Da})$, ovalbumin $(45,000 \mathrm{Da})$, carbonic anhydrase (30,000 Da), myoglobin $(17,200 \mathrm{Da})$, cytochrome c $(12,300$ Da). The staining procedure was done with Coomassie Blue R350. Gel filtration was performed as described above using the following protein calibration kit: cytochrome c (12,300 Da), carbonic anhydrase (30,000 Da), ovalbumin (45,000 Da), and bovine albumin $(67,000 \mathrm{Da})$.

\section{Effect of pH and Temperature on Endoglucanase Activity and Stability}

The effect of $\mathrm{pH}$ and temperature was evaluated in the range of $\mathrm{pH} 2.5-8.0(\mathrm{pH}$ interval 0.5$)$ and temperature of 30-90 ${ }^{\circ} \mathrm{C}$ (temperature interval $5{ }^{\circ} \mathrm{C}$ ) by performing the CMCase activity assay. Citrate-phosphate buffer solutions were used for $\mathrm{pH}$ profile determination. Thermal and $\mathrm{pH}$ stabilities were determined by pre-incubating the enzyme at various temperatures, notably, $40^{\circ} \mathrm{C}$ and $60{ }^{\circ} \mathrm{C}$, at $\mathrm{pH} 3.0,5.0$ and 7.0 for up to $210 \mathrm{~min}$. At every $15 \mathrm{~min}$ a sample was withdrawn and the residual activity of the enzyme was determined. 
Estimation of Endoglucanase Substrate Specificity and Kinetic Parameters

The substrate specificity of endoglucanase was tested with $10 \mathrm{mg} / \mathrm{mL}$ carboxymethyl cellulose (CMC), cellobiose, and methyl glycoside (Sigma) by determination of the reducing sugars released. When $1.0 \mathrm{mM} \quad \rho$-nitrophenyl- $\beta$-Dglucopyranoside (Sigma) was used as a substrate, the activity was determined as described by Ponpium (17). The enzyme activity against filter paper was determined with $50 \mathrm{mg}$ Whatman No 1 filter paper soaked in $1.8 \mathrm{~mL}$ of $100 \mathrm{mM}$ sodium acetate buffer with $\mathrm{pH}$ 5. The enzyme reaction was performed at $50{ }^{\circ} \mathrm{C}$ for $60 \mathrm{~min}$ and the increase in reducing sugars was assayed.

Kinetic parameters were determined using $\mathrm{CMC}$ as a substrate in the range of 4.0-9.0 $\mathrm{mg} / \mathrm{mL}$ initial concentration by applying Lineweaver-Burk transformation.

\section{Hydrolysis of CMC by Endoglucanase}

CMC hydrolysis was studied in the case of $10.0 \mathrm{mg} / \mathrm{mL}$ $\mathrm{CMC}$ with $0.08 \mathrm{U}$ of endoglucanase at $\mathrm{pH} 5.0$ and $40{ }^{\circ} \mathrm{C}$. The relative viscosity of CMC solution was measured with an Oswald viscometer (5) and the reducing sugars content in the reaction mixture was determined.

\section{Synergism of Endoglucanase and Endoxylanase Action}

The synergistic effect of endoglucanase and endoxylanase was evaluated by the hydrolysis degree of corn cobs. Endoxylanase was isolated from the culture liquid of Aspergillus niger B03 as described previously (8). Three samples, containing respectively endoglucanase, endoxylanase and both enzyme preparations were prepared. $10 \mathrm{mg} / \mathrm{mL}$ of corn cobs (milled to $<1 \mathrm{~mm}$ ) were suspended in $100 \mathrm{mM}$ sodium acetate buffer with pH 5.0 and $3.2 \mathrm{U}$ of endoglucanase and $70 \mathrm{U}$ of endoxylanase were added per one gram of substrate. The hydrolysis was performed at $40{ }^{\circ} \mathrm{C}$ for up to 10 h. At certain time intervals the reducing sugars released were determined. The synergistic effect is evaluated in comparison to the theoretical values of the reducing sugars, formed by both enzyme preparations.

\section{Determination of CMCase Activity}

CMCase activity was determined by mixing $0.2 \mathrm{~mL}$ enzyme solution with $1.8 \mathrm{~mL}$ of $10.0 \mathrm{mg} / \mathrm{mL} \mathrm{CMC} \mathrm{solution} \mathrm{in}$ $100 \mathrm{mM}$ sodium acetate buffer with $\mathrm{pH} 5.0$, at $50{ }^{\circ} \mathrm{C}$ for 15 min and the reducing sugars released were determined. One unit of CMCase activity was defined as the amount of enzyme, forming $1 \mu \mathrm{mol}$ of reducing sugars per one minute under the assay conditions.

\section{Assays}

The concentration of reducing sugars was determined by the dinitrosalicylic acid method (13). Protein content was assayed by the Lowry method (12) with bovine serum albumin (Sigma) as a standard. Biomass concentration was determined by the dry weight after drying at $105^{\circ} \mathrm{C}$.

\section{RESULTS AND DISCUSSION}

\section{Biosynthesis of Endoglucanase}

The dynamics of biosynthesis and Aspergillus niger growth in submerged cultivation in $15 \mathrm{~L}$ stirred and aerated laboratory bioreactor is shown on Fig. 1. The period within 15$35 \mathrm{~h}$ was the $\log$ phase of the strain growth and it was characterized with a sharp increase of biomass production and outlet $\mathrm{CO}_{2}$. Endoglucanase biosynthesis began after $45 \mathrm{~h}$ of fermentation. According to biomass and $\mathrm{CO}_{2}$ production more significant increase in endoglucanase biosynthesis was observed at the end of log phase and continued during the stationary phase of strain growth.

After $20 \mathrm{~h}$ of fermentation a tendency of decrease in $\mathrm{pH}$ of the culture medium was observed (data not shown). Significant increase in CMCase activity was observed at $\mathrm{pH}$ within 3.04.0. Maximum enzyme activity $(3.7 \mathrm{U} / \mathrm{mL})$ was achieved after $95 \mathrm{~h}$ of fermentation at $\mathrm{pH} 4.0$.

Reducing sugars concentration gradually decreased during 
the process. Increase in CMCase activity and medium $\mathrm{pH}$ began after the complete run out of reducing sugars, which is probably due to the use of the obtained organic acids as carbon source.

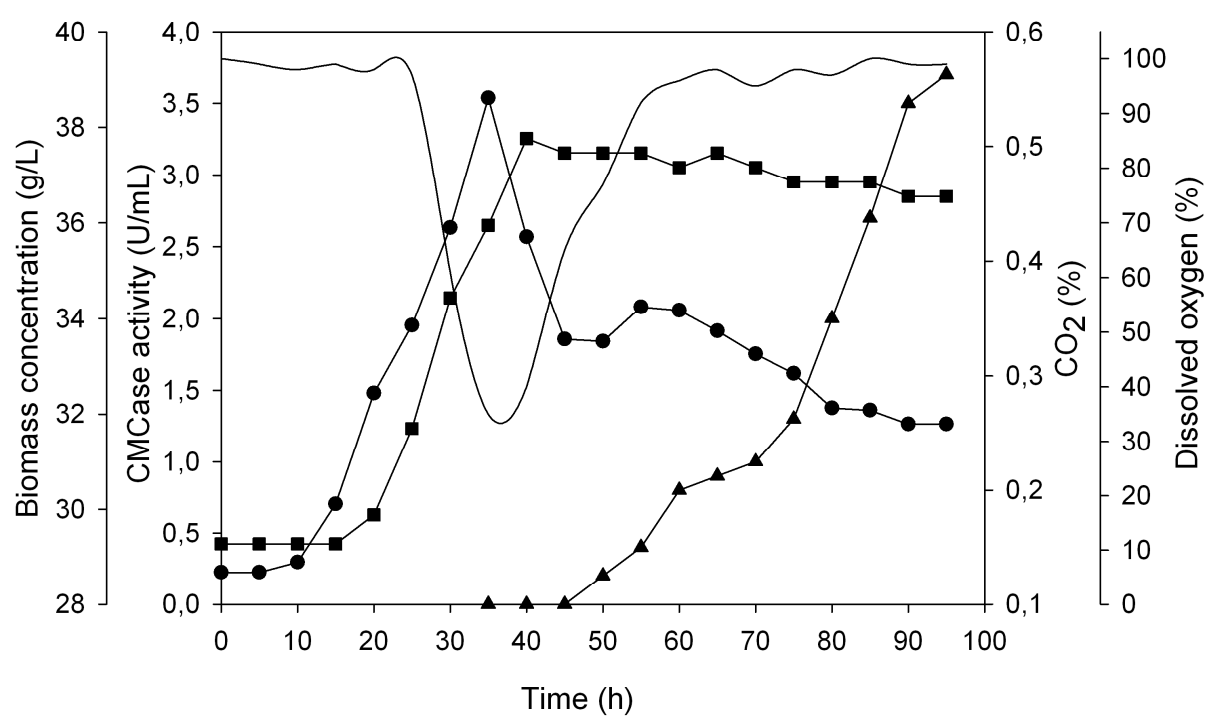

Figure 1. Dynamics of endoglucanase biosynthesis and strain cultivation: ( $\boldsymbol{\square})$ biomass concentration; ( $\mathbf{\Delta})$ CMCase activity; $\mathrm{CO}_{2} ;(-)$ dissolved oxygen

\section{Purification and Molecular Weight of Endoglucanase}

The extracellular endoglucanase produced by Aspergillus niger B03 was purified using three consecutive steps (ultrafiltration and column chromatography). A summary of the purification procedure is presented in Table 1. The ultrafiltration step yielded $91.35 \%$ of CMCase activity in the retentate. For further purification, the retentate was subjected to anion-exchange chromatography on DEAE-Sephadex A50 (Fig. 2). Only one peak showing CMCase activity was detected.
On this stage of the purification procedure the enzyme did not appear as a single band on SDS-PAGE, which imposed the need of further purification by gel filtration with Sephadex G75. After this step endoglucanase was detected as a single band on the electropherogram, indicating a homogeneous enzyme (Fig. 3).

The molecular weight of the purified endoglucanase was determined to be 26,900 Da by SDS-PAGE and 28,800 Da by gel filtration. The close values, achieved by both methods suggested it to be a monomer protein.

Table 1. Procedures for endoglucanase purification

\begin{tabular}{llllll}
\hline Purification step & $\begin{array}{l}\text { Total } \\
\text { activity }(\mathbf{U})\end{array}$ & $\begin{array}{l}\text { Total protein } \\
(\mathbf{m g})\end{array}$ & $\begin{array}{l}\text { Specific activity } \\
(\mathbf{U} / \mathbf{m g})\end{array}$ & $\begin{array}{l}\text { Purification } \\
\text { fold (-) }\end{array}$ & $\begin{array}{l}\text { Yield } \\
(\%)\end{array}$ \\
\hline Crude supernatant & 37.00 & 76.00 & 0.49 & 1.00 & 100.00 \\
Ultrafiltration & 33.80 & 51.25 & 0.66 & 1.35 & 91.35 \\
DEAE-Sephadex A50 & 4.35 & 0.99 & 4.41 & 9.00 & 11.76 \\
Sephadex G75 & 2.30 & 0.35 & 6.57 & 13.41 & 6.22 \\
\hline
\end{tabular}




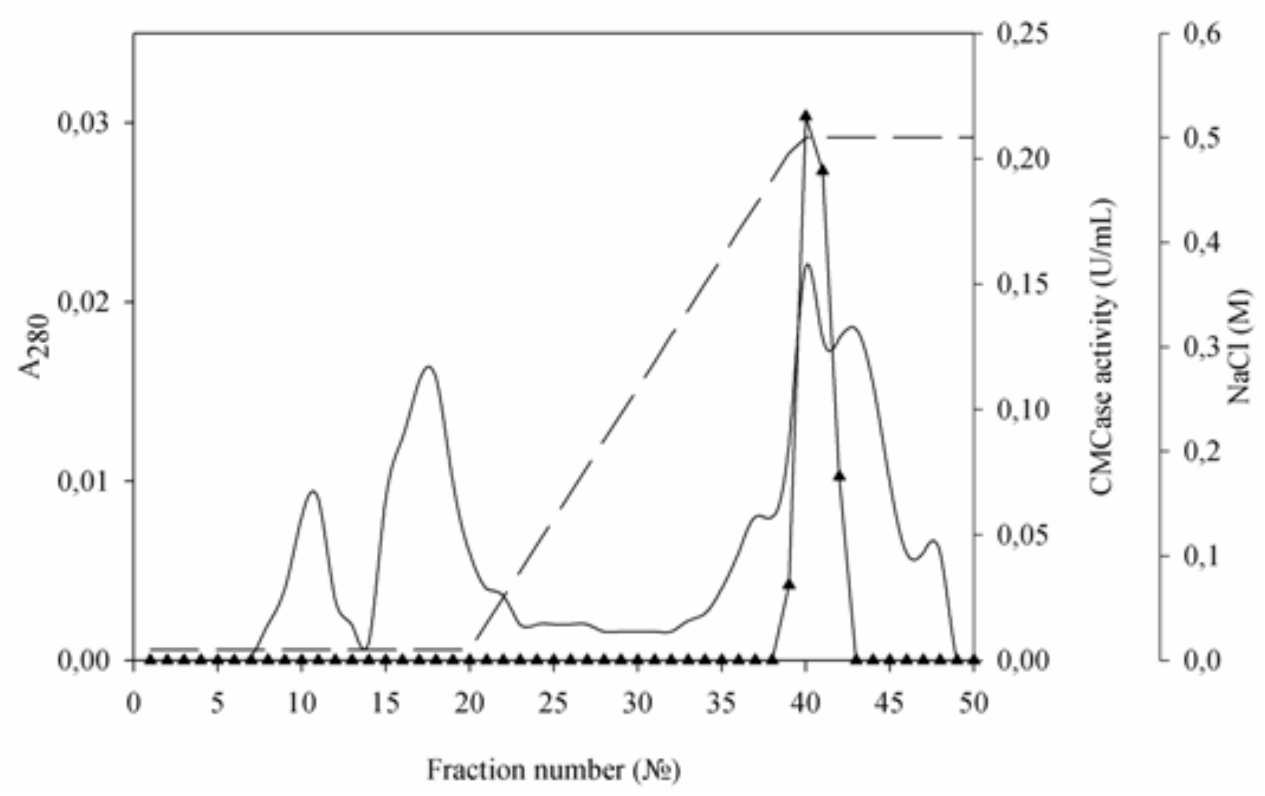

Figure 2. Endoglucanase purification by anion exchange chromatography on DEAE-Sephadex A 50: the symbols ( $\mathbf{\Delta})$ represent CMCase activity, solid lines represent $\mathrm{A}_{280}$ values, and broken lines represent $\mathrm{NaCl}$ concentration

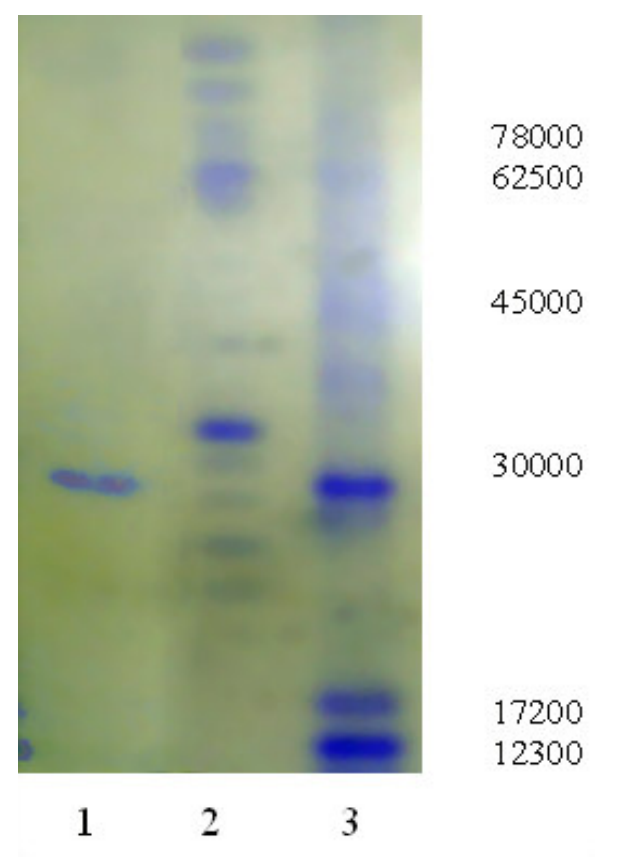

Effect of pH and Temperature on Enzyme Activity and

\section{Stability}

The effect of $\mathrm{pH}$ and temperature was studied with the homogenous and the crude endoglucanase (data not shown). Both enzyme preparations showed maximal CMCase activity
Figure 3. SDS-PAGE of endoglucanase: 1endoglucanase after gel filtration on Sephadex G75, 2-crude enzyme preparation, 3-protein calibration kit (ovotransferrin 78,000 Da, albumin $66,250 \mathrm{Da}$, ovalbumin 45,000 Da, carbonic anhydrase 30,000 Da, myoglobin 17,200 Da, cytochrome c $12,300 \mathrm{Da})$ at $\mathrm{pH} 3.5$, and $80 \%$ relative activity was detected in the range of $\mathrm{pH} 2.5-4.5$.

The homogenous and the crude enzyme preparations showed a high activity at high temperature values. The optimal temperature value was $65^{\circ} \mathrm{C}$ and both enzymes displayed over 
$90 \%$ of their maximal activity at $75{ }^{\circ} \mathrm{C}$. The crude endoglucanase showed catalytic activity (25\% of maximal one) even at $95{ }^{\circ} \mathrm{C}$. This property of endoglucanase is important for its application.

An important feature of the industrially applied enzymes is their stability. The enzyme showed a good stability at low values of $\mathrm{pH}$ (data not shown). When endoglucanase was incubated at $40{ }^{\circ} \mathrm{C}$ and $\mathrm{pH} 3.0$, the enzyme retained $92 \%$ of its activity for $210 \mathrm{~min}$. For comparison in the case of $\mathrm{pH} \mathrm{7.0,}$ endoglucanase was totally inactivated for $90 \mathrm{~min}$. At higher temperature values $\left(60^{\circ} \mathrm{C}\right.$ and $\left.\mathrm{pH} 3.0\right)$ the enzyme showed 60 $\%$ residual activity for $45 \mathrm{~min}$.

\section{Substrate Specificity and Kinetic Parameters of Endoglucanase}

The substrate specificity of the homogenous enzyme preparation was studied with CMC, filter paper, cellobiose, methyl glycoside and $\rho$-nitrophenyl- $\beta$-D-glucopyranoside. The enzyme showed highest activity against CMC. The activity was lower, when filter paper was used as a substrate. The enzyme did not degrade low molecular substrates such as cellobiose, methyl glycoside, and $\rho$-nitrophenyl- $\beta$-D-glucopyranoside.
These results indicated that the enzyme is an endoglucanase it displayed high activity against CMC, low activity against filter paper, and did not act on glycosides. Similar results were reported for the endoglucanase produced by Aspergillus kawachii (9).

The kinetic parameters of endoglucanase were determined in the case of $\mathrm{CMC}$ as a substrate. $\mathrm{K}_{\mathrm{m}}$ value was estimated to be $21.01 \mathrm{mg} / \mathrm{mL}$, and $\mathrm{V}_{\max }$ was $0.31 \mathrm{mg} / \mathrm{mL} . \mathrm{min}$. The established value of $\mathrm{K}_{\mathrm{m}}$ was significantly higher than the values reported for other endoglucanases from Aspergillus $-\mathrm{K}_{\mathrm{m}}$ $=14 \mathrm{mg} / \mathrm{mL}$ (16), $\mathrm{K}_{\mathrm{m}}=5 \mathrm{mg} / \mathrm{mL}$ (21), which showed lower affinity of the isolated endoglucanase against substrate CMC.

\section{CMC Hydrolysis by Endoglucanase}

CMC hydrolysis was studied by assaying the change in the relative viscosity and the reducing sugars content (Fig. 4). A sharp decrease of CMC viscosity and a corresponding increase in reducing sugars content was detected during the first $15 \mathrm{~min}$ of the reaction. The rates of viscosity decrease and reducing sugars increase were reduced after 15 min of reaction. These results confirmed the hypothesis that the enzyme is an endoglucanase.

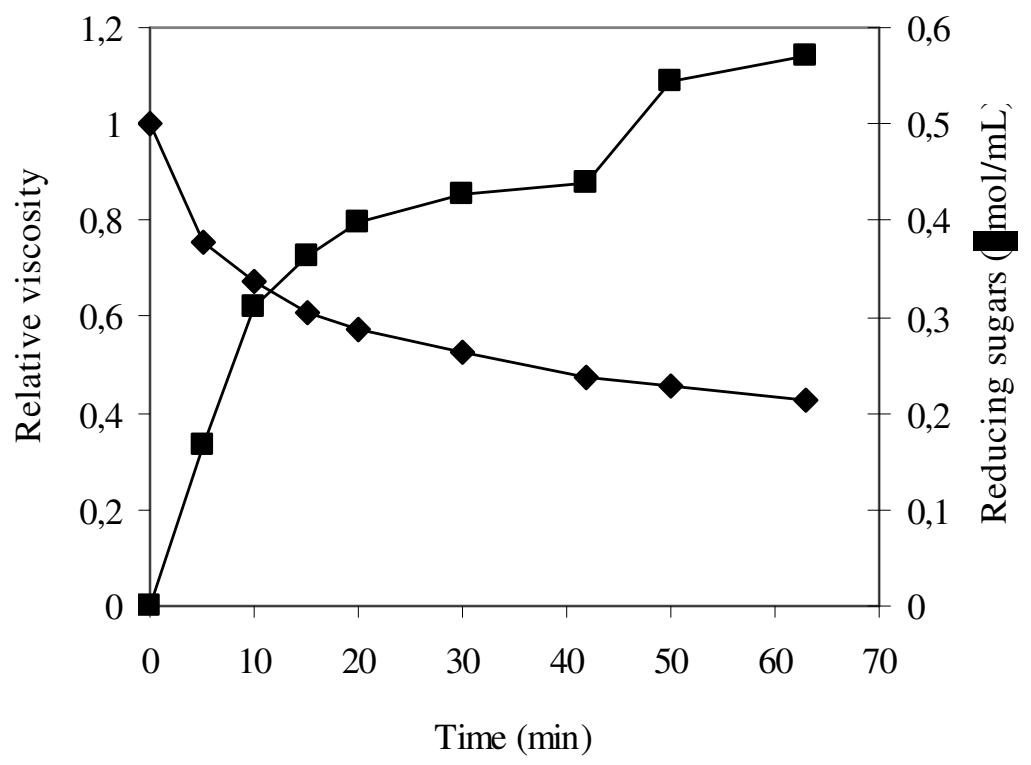

Figure 4. CMC hydrolysis by endoglucanase: $(\bullet)$ relative viscosity, ( $\mathbf{\square})$ reducing sugars 


\section{Synergism of Endoglucanase and Endoxylanase Action}

The synergistic effect of endoglucanase and endoxylanase was studied by performing hydrolysis of corn cobs by the single and combined action of both enzymes (Fig. 5). The corn cobs used were a complex substrate, containing $9.57 \% \beta$-glucans and 35.56 $\%$ arabonoxylans (6). The results showed that the substrate is more effectively hydrolyzed by the combined action of endoglucanase and endoxylanase in comparison to the separate enzymes.
Furthermore, a synergistic effect was observed. The concentration of reducing sugars formed by both enzymes was higher than the theoretically calculated value. At the end of the process the increase was about $50 \%$. These results may be explained by the degradation of xylan networks between cellulose microfibrils, which allows endoglucanase to degrade cellulose microfibrils in the deeper structure (14). Similar synergistic effect was reported for other xylan and cellulose degrading enzymes $(14,15)$.

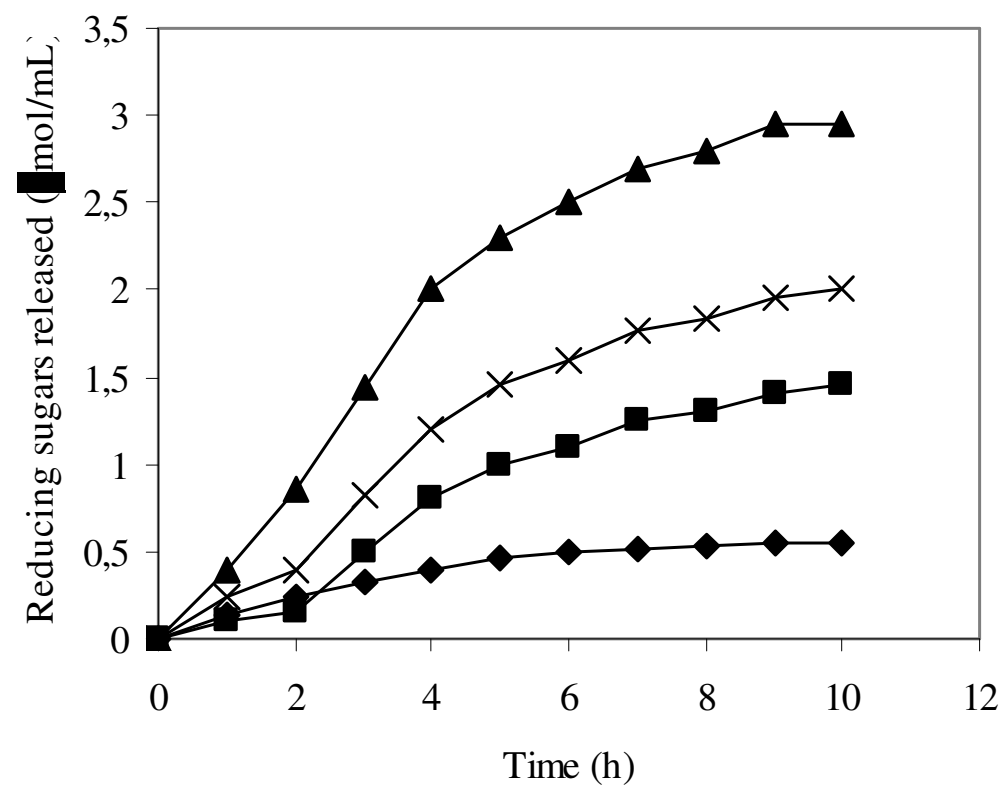

Figure 5. Synergism of endoglucanase and endoxylanase in degradation of corn cobs: $(\boldsymbol{\square})$ endoglucanase, $(\bullet)$ endoxylanase, $(\boldsymbol{\Delta})$ endoglucanase and endoxylanase, $(x)$ values obtained with theoretical calculations

\section{CONCLUSION}

An endoglucanase was isolated from the culture liquid from a xylanase producing strain Aspergillus niger B03. The enzyme was highly active against $\mathrm{CMC}$, it showed lower activity against filter paper, did not act on $\beta$-glycosides, and caused a decrease in CMC viscosity. These results indicated that the enzyme is an endoglucanase. The isolated endoglucanase degraded complex substrates as corn cobs in synergism with an endoxylanase, which allows the enzyme to be applied in hydrolysis of lignocellulosic biomass.

\section{ACKNOWLEDGEMENTS}

The authors acknowledge Biovet Ltd. for giving the xylanase producing strain Aspergillus niger B03. The work was supported by the Grant-in-Aid VU-AN-6/2005 for Scientific Research of Priority area (Agricultural science) from the Ministry of Education of Bulgaria.

\section{REFERENCES}

1. Ali, U.F.; Saad El-Dein, H.S. (2008). Production and partial purification 
of cellulase complex by Aspergillus niger and A. nidulans grown on water hyacinth blend. J. Appl. Sci. Res. 4, 875-891.

2. Beg, Q.K.; Kapoor, K.; Mahajan, L.; Hoondal, G.S. (2001). Microbial xylanases and their industrial applications: a review. Appl. Microbiol. Biotechnol. 56, 326-338.

3. Bonnin, E.; Brunel, M.; Gouy, Y.; Lesage-Meesen, L; Asther, M.; Tribault, J.F. (2001). Aspergillus niger I-1472 and Pycnoporus cinnabarinus MUCL 39533, selected for the biotransformation of ferulic acid to vanillin, are also able to produce cell wall polysaccharidedegrading enzymes and feruloyl esterases. Enzyme Microbial Technol. 28, 70-80.

4. da Silva, R.; Lago, E.S.; Merheb, C.W.; Macchione, M.M.; Park, Y.K.; Gomes, E. (2005). Production of xylanase and CMCase on solid state fermentation in different residues by Thermoascus aurantiacus Miehe. Braz. J. Microbiol. 36, 235-241.

5. Delcheva, G.; Pishtiyski, I.; Dobrev, G.; Krusteva, S. (2007). Immobilization of Aspergillus niger pectinase on polyacrylonitrile copolymer membrane. Trends Appl. Sci. Res. 2, 419-425.

6. Delcheva, G.; Dobrev, G.; Pishtiyski, I. (2008). Performance of Aspergillus niger B $03 \quad \beta$-xylosidase immobilized on polyamide membrane support. J. Mol. Catal. B: Enzymatic 54, 109-115.

7. Dobrev, G.T.; Pishtiyski, I.G.; Stanchev, V.S.; Mircheva, R. (2007). Optimization of nutrient medium containing agricultural wastes for xylanase production by Aspergillus niger B03 using optimal composite experimental design. Biores. Technol. 98, 2671-2678.

8. Dobrev, G.; Zhekova, B.; Delcheva, G.; Koleva, L.; Tziporkov, N.; Pishtiyski, I. (2009). Purification and characterization of endoxylanase Xln-1 from Aspergillus niger B03. World J. Microbiol. Biotechnol. 25, 1043-1049.

9. Koseki, T.; Mese, Y.; Fushinobu, S.; Masaki, K.; Fujii, T.; Ito, K.; Shiono, Y.; Murayama, T.; Iefuji. H. (2008). Biochemical characterization of a glycoside hydrolase family 61 endoglucanase from Aspergillus kawachii. Appl. Microbiol. Biotechnol. 77, 1279-1285.

10. Kumar, R.; Wyman, C.E. (2009). Effect of xylanase supplementation of cellulase on digestion of corn stover solids prepared by leading pretreatment technologies. Biores. Technol. 100, 4203-4213.
11. Laemli, U.K. (1970). Cleavage of structural proteins during the assembly of the head of bacteriophage T4. Nature 227, 680-685.

12. Lowry, O.; Rosebrough, N.; Farr, A.; Randall, R. (1951). Protein measurement with the Folin phenol reagent. J. Biol. Chem. 193, 265-275.

13. Miller, G.L. (1959). Use of dinitrosalicylic acid reagent for determination of reducing sugar. Anal. Chem. 31, 426-428.

14. Murashima, K.; Kosugi, A.; Doi, R.H. (2003). Synergistic effects of cellulosomal xylanase and cellulases from Clostridium cellulovorans on plant cell wall degradation. J. Bacteriol. 185, 1518-1524.

15. Nunes, M.F.; da Cunha-Santino, M.B.; Bianchini, I. (2011). Xylanase and cellulase activities during anaerobic decomposition of three aquatic macrophytes. Braz. J. Microbiol. 42, 75-83.

16. Onyike, E.; Auta, R.; Nok, A.J. (2008). Isolation, partial purification and characterization of endoglucanase (EC.3.2.1.4) from Aspergillus niger S.L.1 using corn cobs as carbon source. Niger. J. Biochem. Mol. Biol. 23, $1-11$.

17. Ponpium, P.; Ratanakhanokchai, K.; Kyu, K. (2000). Isolation and properties of a cellulosome-type multienzyme complex of the thermophilic Bacteroides sp. strain P-1. Enzyme Microbial. Technol. 26, 459-465.

18. Robison, P.D. (1984). Cellulase and xylanase production by Trichoderma reesei RUT C-30. Biotechnol. Letters 6, 119-122.

19. Sánchez, C. (2009). Lignocellulosic residues: Biodegradation and bioconversion by fungi. Biotechnol. Adv. 27, 185-194.

20. Selig, M.J.; Knoshaug, E.P.; Adney, W.S., Himmel, M.E.; Decker, S.R. (2008). Synergistic enhancement of cellobiohydrolase performance on pretreated corn stover by addition of xylanase and esterase activities. Biores. Technol. 99, 4997-5005.

21. Tao, Y-M.; Zhu, X-Z.; Huang, J-Z.; Ma, S-J.; Wu, X-B.; Long, M-N.; Chen, Q-X. (2010). Purification and properties of endoglucanase from sugar cane bagasse hydrolyzing strain, Aspergillus glaucus XC9, J. Agric. Food Chem. 58, 6126-6130.

22. Vries, R.P.; Visser, J. (2001). Aspergillus enzymes involved in degradation of plant cell wall polysaccharides. Microbiol. Mol. Biol. Rev. $65,497-522$. 